\title{
REDEFINISI GENDER DAN SEKS
}

\author{
Ade Kartini \\ MAS Al-Choeriyyah Cibeas Tasikmalaya \\ akartini76@gmail.com \\ Asep Maulana \\ Institut Agama Islam Cipasung Tasikmalaya \\ asepmaulana8464@gmail.com
}

\begin{abstract}
The development of an increasingly advanced world opens up opportunities for everyone, both men and women, to take part openly in various fields of life. This is inseparable from the role and figure of women, whose work today cannot be ruled out, thus constructing gender equality, which means the claim that bumans between men and women are created as creatures and that differences only lie in the quality and level of piety. There is no claim that men or women are special before God, so whoever wants to gain a high degree must be cautious. There is no reason for the difference between men and women in the capacity of humans as creatures. Both have the same potential and opportunities to become ideal beings. Thus, a comprebensive understanding of the conceptual gender and perceptions between gender and sex is very necessary and important to understand correctly. This library research is conducted through documentation study and qualitative analysis. The findings of the research result state that gender is a concept that examines the differences between men and women as a result of social construction which can take the form of differences in roles, functions, and responsibilities between men and women so that they can change according to different times. gender that has been outlined by nature.
\end{abstract}

\section{Keywords: Redefinition, Gender, Sex}

\section{Abstrak}

Perkembangan dunia yang semakin maju membukakan kesempatan bagi setiap orang baik laki-laki maupun perempuan untuk berkiprah secara terbuka di berbagai bidang kehidupan. Hal tersebut tidak lepas dari peran 


\section{Ade Kartini, Asep Maulana}

dan sosok perempuan yang hari ini kiprahnya tak bisa dikesampingkan sehingga mengonstruksi kesetaraan gender yang berarti klaim bahwa manusia antara laki-laki dan perempuan sama-sama diciptakan sebagai makhluk dan perbedaan pun hanyalah terletak pada kualitas dan kadar ketakwaannya. Tak ada klaim laki-laki ataupun perempuan yang menjadi istimewa di hadapan Tuhan, maka barang siapa yang ingin memperoleh derajat yang tinggi maka hendaklah bertakwa. Tidak ada alasan perbedaan antara laki-laki dan perempuan dalam kapasitas manusia sebagai makhluk. Keduanya mempunyai potensi dan peluang yang sama untuk menjadi makhluk yang ideal. Dengan demikian pemahaman tentang konseptual gender dan persepsi antara gender dengan seks yang komprehensif sangat diperlukan dan penting untuk dipahami secara benar. Penelitian kepustakaan ini dilakukan melalui studi dokumentasi dan analisis data kualitatif. Temuan hasil penelitian menyatakan bahwa gender adalah suatu konsep yang mengaji tentang perbedaan antara laki-laki dan perempuan sebagai hasil kontruksi sosial yang dapat berbentuk perbedaan peran, fungsi, dan tanggung jawab antara laki-laki dan perempuan sehingga dapat berubah sesuai dengan perkembangan jaman berbeda halnya dengan jenis kelamin yang telah digariskan secara kodrati.

\section{Kata Kunci : Redefinisi, Gender, Seks}

\section{Pendahuluan}

Perkembangan dunia yang semakin pesat di jaman ini menimbulkan beberapa persoalan yang pelik. Perubahan zaman berdampak adanya beberapa pergeseran di setiap lini kehidupan mulai dari ilmu pengetahuan dan teknologi sampai kepada penyadaran diri dan pemikiran. Perkembangan dunia yang semakin maju membukakan kesempatan bagi setiap orang untuk berkiprah secara ter- buka di berbagai bidang kehidupan. Tak ayal tersebut tidak lepas dari peran dan sosok seorang perempuan yang hari ini kiprahnya tak bisa dikesampingkan. Banyak bidang yang semula dipegang oleh kaum Adam kini bergeser mampu ditempati oleh kaum Hawa. Peran perempuan di sini ternyata mampu setara dengan kaum laki-laki.

Persoalan muncul tatkala ada persepsi negatif dan ketid- 
Vol. 12, No. 2, Oktober 2019

p-ISSN:2086 -0749

e-ISSN:2654-4784

akberterimaan sebagian masyarakat terhadap peran perempuan di dunia publik. Adanya hal tersebut memunculkan pemikiran yang tidak sehat di beberapa kalangan atau di sebagian masyarakat, yang bisa menimbulkan debat kusir berkepanjangan. Hal ini perlu diluruskan kembali mengingat kaum perempuan pun bisa berperan aktif dalam melestarikan dan mengupayakan hal-hal di luar dunia domestik.

Secara fitrah perempuan dan laki-laki dilahirkan dengan peran dan fungsi yang tidak sama hal ini telah difirmankan Allah dalam surat Ali-Imran ayat 36 yang berbunyi:

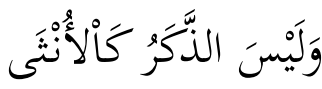

Artinya: dan anak laki-laki tidaklah seperti anak perempuan Maksud dari ayat tersebut jelas bahwa sosok laki-laki dan perempuan memang berbeda. Sosok yang dimaksud di sini adalah sosok biologis dan fisiologis yang dimiliki oleh setiap jenis kelamin. Perbedaan ini akhirnya terletak pada ranah fungsi tadi saja karena sesungguhnya di mata $\mathrm{Al}$ lah perempuan dan laki-laki pun punya kedudukan yang sama. Hal ini terdapat dalam salah satu ayat surat al-Hujurat ayat 13 yang berbunyi:

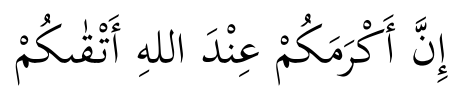

Artinya: sesunggubnya yang paling mulia di sisi Allab adalab (orang) yang paling bertakwa di antara kalian.

Hal mendasar dalam Alquran tentang konsep kesetaraan gender adalah klaim bahwa manusia antara laki-laki dan perempuan sama-sama dicip- 


\section{Ade Kartini, Asep Maulana}

takan sebagai hamba. ${ }^{1}$ Perbedaan hanyalah terletak dari segi takwa. Tak ada klaim laki-laki ataupun perempuan yang menjadi istimewa di hadapan Tuhan, artinya, maka barang siapa yang ingin memperoleh derajat yang tinggi maka hendaklah bertakwa. ${ }^{2}$

Berdasarkan hal itu, tidak ada alasan perbedaan antara lakilaki dan perempuan dalam kapasitas manusia sebagai hamba. Keduanya mempunyai potensi dan peluang yang sama untuk menjadi hamba yang ideal. Barometer yang digunakan Tuhan dalam menilai tingkat ideal manusia diukur dari aspek ketakwaannya. Oleh karena itu, untuk mencapai derajat muttaqin, tidak di kenal adanya perbedaan jenis kelamin, warna kulit, ras, suku bangsa atau etnis tertentu.

\footnotetext{
1 Nasaruddin Umar, Argument Kesetaraan Jender Perspektif Al-Qur'an, Jakarta: Paramadina, 2001), hlm. 248.

2 Ahmad Mushthafa al-Maraghi, Terjemah Tafsir Al-Maraghi, jilid 26, cet. 1, (Semarang: Toha Putra, 1989), hlm. 237
}

Untuk meluruskan hal tersebut di atas, perlu dibahas secara tajam tentang konsep gender yang sebenarnya. Makalah ini akan memuat beberapa konsep gender yang bisa menjadi acuan dasar dalam menilik masalah gender. Rumusan masalah dalam penelitian ini antara lain: 1) bagaimanakah yang dimaksud dengan konsep dan teori gender itu? 2) bagaimanakah persepsi antara konsep gender dengan seks? Penelitian ini menguraikan tentang konsep gender berikut teori dan istilah-istilah yang berkenaan dengan pembahasan gender. Pembahasan tidak melebar pada kenyataan dan permasalahan praktis mengenai gender dalam kehidupan nyata. Hasil temuan ini diharapkan dapat memberikan kontribusi akan pentingnya pengetahun tentang konsep gender dan seks yang komprehensif dan benar dalam khazanah keilmuan dunia. Penelitian kepustakaan ini dil- 
Vol. 12, No. 2, Oktober 2019

p-ISSN:2086 -0749

e-ISSN:2654-4784

akukan melalui studi dokumentasi dan analisis data kualitatif.

\section{Pembahasan}

\section{Konsep dan Teori Gender \\ a. Pengertian Gender}

Istilah gender diperkenalkan oleh para ilmuwan sosial untuk menjelaskan perbedaan perempuan dan laki-laki yang bersifat bawaan sebagai ciptaan Tuhan dan yang bersifat bentukan budaya yang dipelajari dan disosialisasikan sejak kecil. Pembedaan ini sangat penting, karena selama ini sering sekali mencampur adukan ciri-ciri manusia yang bersifat kodrati dan yang bersifat bukan kodrati (gender). Perbedaan peran gender ini sangat membantu kita untuk memikirkan kembali tentang pembagian peran yang selama ini dianggap telah melekat pada manusia perempuan dan lakilaki untuk membangun gambaran relasi gender yang dinamis dan tepat serta cocok dengan kenyataan yang ada dalam masyarakat. ${ }^{3}$ Perbedaan konsep gender secara sosial telah melahirkan perbedaan peran perempuan dan laki-laki dalam masyarakatnya. Secara umum adanya gender telah melahirkan perbedaan peran, tanggung jawab, fungsi, dan bahkan ruang dan tempat saat manusia beraktivitas. Sedemikian rupanya perbedaan gender ini melekat pada cara pandang kita, sehingga kita sering lupa seakanakan hal itu merupakan sesuatu yang permanen dan abadi sebagaimana kepermanenan dan

\footnotetext{
${ }^{3}$ Sri Sundari Sasongko, Konsep dan Teori Gender, Program Pembinaan Jarak Jauh Pengarusutamaan Gender Modul 2, cet.2, Jakarta: Pusat Pelatihan Gender dan Peningkatan Kualitas Perempuan, 2009), hlm. 6
} 


\section{Ade Kartini, Asep Maulana}

keabadian ciri biologis yang dimiliki oleh perempuan dan laki-laki. ${ }^{4}$ Istilah gender, ${ }^{5}$ belum ada dalam perbendaharaan kamus besar Bahasa Indonesia. Kata gender berasal dari Inggris, gender berarti jenis kelamin. ${ }^{6}$ Gender dapat diartikan sebagai perbedaan antara laki-laki dan perempuan dilihat dari segi nilai dan perilaku. Secara kodrat, nilai dan perilaku. Secara kodrat, memang diakui adanya perbedaan (discrimination) antara laki-laki dengan perempuannya yaitu dalam aspek biologis. Perbedaan secara biologis antara lakilaki dengan perempuan yaitu senantiasa digunakan untuk

4 Herien Puspitawati, Gender dan Keluarga: Konsep dan Realita di Indonesia, (Bogor: PT IPB Press: 2012), hlm. 23

5 Sebagai suatu konsep (belum menggunakan istilah gender), pertama kali dituliskan oleh Antropolog permpuan, Margaret Mead. Perilaku laki-laki dan perempuan adalah produksi budaya, dalam bukunya Sex \& Temperament in 3 Primitive Societies (1935). Lihat dalam makalah pelatihan, "Cefil, Civic Education and Future Indonesian Leaders", di Satunama Yogyakarta: 1-30

6 Nasaruddin Umar, Argument Kesetaraan Jender Perspektif Al-Qur'an, (Jakarta: Paramadina, 2001), hlm. 33. menentukan dalam relasi gender, seperti pembagian status, hak-hak, peran, dan fungsi di dalam masyarakat. Padahal, gender yang dimaksud adalah mengacu kepada peran perempuan dan laki-laki yang dikontruksikan secara sosial. Dimana peran-peran sosial tersebut dikontruksikan secara sosial.

Dimana peran-peran sosial tersebut bisa dipelajari, berubah dari waktu ke waktu, dan beragam menurut budaya dan antar budaya.

Berkenaan dengan pemaknaan gender, ${ }^{8}$ Ann Oakley' sebagaimana dikutip oleh Ahmad

7 Istibsyaroh, Hak-Hak Perempuan: Relasi Jender menurut Tafsir Al-Sya'rawi, (Jakarta: Teraju, 2004), hlm. 3.

${ }^{8}$ Heddy Shri Ahimsa membedakan pemaknaan gender menjadi beberapa pengertian, yakni (1) gender sebagai sebuah istilah asing dengan makna tertentu; (2) gender sebagai suatu fenomena sosial budaya ; (3) gender sebagai suatu kesadaran sosial ; (4) gender sebagai suatu persoalan sosial budaya; (5) gender sebagai sebuah konsep untuk analisis; dan (6) gender sebagai sebuah perspektif untuk memandang kenyataan. Lihat Mochamad Sodik dan Inayah Rohmaniyah (eds), Perempuan Tertindas; Kajian Hadits-hadits "Misoginis", Yogyakarta; PSW IAIN Sunan Kalijaga, 2003, hlm. 22.

9 Anne Oakley, ahli sosiologi Inggris, adalah orang yang mula-mula membedakan istilah "seks" dan "gender". 
Vol. 12, No. 2, Oktober 2019

p-ISSN:2086 -0749

e-ISSN:2654-4784

Baidowi, ${ }^{10}$ mendifinisikan bahwa gender adalah perbedaan perilaku antara perempuan dan laki-laki yang dikonstruk secara sosial, diciptakan oleh laki-laki dan perempuan sendiri, oleh karena itu merupakan persoalan budaya. Gender merupakan perbedaan yang bukan biologis dan bukan kodrat Tuhan. Perbedaan biologis adalah perbedaan jenis kelamin yang bermuara dari kodrat Tuhan. Perbedaan jenis kelamin yang bermuara dari kodrat Tuhan, sementara gender adalah perbedaan yang bukan kodrat Tuhan, tetapi diciptakan oleh laki-laki dan perempuan melalui proses sosial budaya yang panjang.

Kata "gender" dapat diartikan sebagai perbedaan peran, fungsi, status dan tanggungjawab

10 Ahmad Baidowi, Tafsir Feminis; Kajian Perempuan dalam Al-Qur'an dan Para Mufasir Kontemporer, (Bandung: Nuansa, 2005), hlm. 30. pada laki-laki dan perempuan sebagai hasil dari bentukan (konstruksi) sosial budaya yang tertanam lewat proses sosialisasi dari satu generasi ke generasi berikutnya. Dengan demikian gender adalah hasil kesepakatan antar manusia yang tidak bersifat kodrati. Oleh karenanya gender bervariasi dari satu tempat ke tempat lain dan dari satu waktu ke waktu berikutnya. Gender tidak bersifat kodrati, dapat berubah dan dapat dipertukarkan pada manusia satu ke manusia lainnya tergantung waktu dan budaya setempat. ${ }^{11}$

Definisi gender menurut berbagai pustaka adalah sebagai berikut ${ }^{12}$ :

1) "Gender adalah perbedaan antara laki-laki dan perempuan dalam peran, fungsi, hak,

11 Herien Puspitawati, Gender dan Keluarga: Konsep dan Realita di Indonesia, (Bogor: PT IPB Press, 2012), hlm. 27

12 Herien Puspitawati, Gender dan Keluarga: ..., hlm.32 


\section{Ade Kartini, Asep Maulana}

tanggung jawab, dan perilaku yang dibentuk oleh tata nilai sosial, budaya dan adat istiadat dari kelompok masyarakat yang dapat berubah menurut waktu serta kondisi setempat. Tanggung jawab dan perilaku yang dibentuk oleh tata nilai sosial, budaya, dan adat istiadat dari kelompok masyarakat yang dapat berubah menurut waktu serta kondisi setempat.

2) "Gender refers to the economic, social, political, and cultural attributes and opportunities associated with being female and male. The social definitions of what it means to be female or male vary among cultures and changes over time". (gender merujuk pada atribut ekonomi, sosial, politik, dan budaya serta kesempatan yang dikaitkan dengan menjadi seorang perempuan dan laki-laki. Definisi sosial tentang bagaimana artinya menjadi perempuan dan laki-laki beragam menurut bu- daya dan berubah sepanjang jaman).

3) "Gender should be conceptualized as a set of relations, existing in social institutions and reproduced in interpersonal interaction" (Smith 1987; West \& Zimmerman 1987 dalam Lloyd et al. 2009: p.8) (gender diartikan sebagai suatu set hubungan yang nyata di institusi sosial dan dihasilkan kembali dari interaksi antar personal).

4) "Gender is not a property of individuals but an ongoing interaction between actors and structures with tremendous variation across men"s and women"s lives "individually over the life course and structurally in the historical context of race and class" (Ferree 1990 dalam Lloyd et al. 2009: p.8) (Gender bukan merupakan property individual namun merupakan interaksi yang sedang berlangsung antar aktor dan struktur dengan variasi yang sangat besar antara kehidupan laki-laki dan per- 
An-Nisa' : Jurnal Kajian Perempuan \& Keislaman

Vol. 12, No. 2, Oktober 2019

p-ISSN:2086 -0749

e-ISSN:2654-4784

empuan "secara individual" sepanjang siklus hidupnya dan secara struktural dalam sejarah ras dan kelas).

5) "At the ideological level, gender is performatively produced" (Butler 1990 dalam Lloyd et al. 2009: p.8) (Pada tingkat ideologi, gender dihasilkan).

6) "Gender is not a noun- a "being"but a "doing". Gender is created and reinforced discursively, through talk. and behavior, where individuals claim a gender identity and reveal it to others" (West \& Zimmerman 1987 dalam Lloyd et al. 2009: p.8) (Gender bukan sebagai suatu kata benda-"menjadi seseorang", namun suatu "perlakuan". Gender diciptakan dan diperkuat melalui diskusi dan perilaku, dimana individu menyatakan suatu identitas gender dan mengumumkan pada yang lainnya).
7) "Gender theory is a social constructionist perspective that simultaneously examines the ideological and the material levels of analysis" (Smith 1987 dalam Lloyd et al. 2009: p.8) (Teori gender merupakan suatu pandangan tentang konstruksi sosial yang sekaligus mengetahui ideologi dan tingkatan analisis material).

Dengan demikian gender menyangkut aturan sosial yang berkaitan dengan jenis kelamin manusia laki-laki dan perempuan. Perbedaan biologis dalam hal alat reproduksi antara laki-laki dan perempuan memang membawa konsekuensi fungsi reproduksi yang berbeda. Hal tersebut berimbas pada tuntutan peran, tugas, kedudukan, dan kewajiban yang pantas dilakukan oleh lakilaki atau perempuan dan yang tidak pantas dilakukan oleh laki-laki atau perempuan. Dampak yang 


\section{Ade Kartini, Asep Maulana}

dipaparkan di atas kenyataan dan padangannya sangat bervariasi dari masyarakat satu ke masyarakat lainnya.

b. Teori Gender Istilah gender diketengahkan oleh para ilmuwan sosial untuk menjelaskan mana perbedaan perempuan dan lakilaki yang bersifat bawaan sebagai ciptaan Tuhan dan mana yang merupakan tuntutan budaya yang dikonstruksikan, dipelajari dan disosialisasikan. Pembedaan itu sangat penting, karena selama ini kita sering kali mencampuradukkan ciri-ciri manusia yang bersifat kodrati dan tidak berubah dengan ciri-ciri manusia yang bersifat non kodrat (gender) yang sebenarnya bisa berubah - ubah atau diubah. Pembedaan peran gender ini sangat membantu kita untuk memikirkan kembali tentang pembagian peran yang selama ini dianggap telah melekat pada perempuan dan laki- laki. Perbedaan gender dikenal sebagai sesuatu yang tidak tetap, tidak permanen, memudahkan kita untuk membangun gambaran tentang realitas relasi perempuan dan laki-laki yang dinamis yang lebih tepat dan cocok dengan kenyataan yang ada dalam masyarakat. Di lain pihak, alat analisis sosial yang telah ada seperti analisis kelas, analisis diskursus (discourse analysis), dan analisis kebudayaan yang selama ini digunakan untuk memahami realitas sosial tidak dapat menangkap realitas adanya relasi kekuasaan yang didasarkan pada relasi gender dan sangat berpotensi menumbuhkan penindasan. Melihat pandangan tersebut analisis gender sebenarnya menggenapi sekaligus mengkoreksi alat analisis sosial yang ada yang dapat digunakan untuk meneropong realitas relasi sosial lelaki dan perempuan serta akibat-akibat yang ditimbulkannya. Perbedaan konsep gender secara sosial telah melahirkan perbedaan peran perempuan dan laki- laki dalam 
Vol. 12, No. 2, Oktober 2019

p-ISSN:2086 -0749

e-ISSN:2654-4784

masyarakat. Secara umum adanya gender telah melahirkan perbedaan peran, tanggung jawab, fungsi, dan bahkan ruang dan tempat saat manusia beraktivitas. Sedemikian rupanya perbedaan gender itu melekat pada cara pandang masyarakat, sehingga masyarakat sering lupa seakanakan hal itu merupakan sesuatu yang permanen dan abadi sebagaimana permanen dan abadinya ciri-ciri biologis yang dimiliki oleh perempuan dan lakilaki. Secara sederhana perbedaan gender telah melahirkan pembedaan peran.

Dalam pembahasan mengenai gender, termasuk kesetaraan dan keadilan gender dikenal adanya 2 aliran atau teori yaitu teori nurture dan teori nature. Terlepas dari hal tersebut dapat pula dikembangkan satu konsep teori yang diilhami dari dua konsep teori tersebut yang merupakan kompromistis atau keseimbangan yang disebut dengan teori equilibrium.

1) Teori Nurture

Menurut teori nurture adanya perbedaan perempuan dan laki - laki adalah hasil konstruksi sosial budaya sehingga menghasilkan peran dan tugas yang berbeda. Perbedaan itu membuat perempuan selalu tertinggal dan terabaikan peran dan kontribusinya dalam kehidupan berkeluarga, bermasyarakat, berbangsa dan bernegara. Konstruksi sosial menempatkan perempuan dan laki - laki dalam perbedaan kelas. Laki - laki diidentikkan dengan kelas borjuis, dan perempuan sebagai kelas proletar.

2) Teori Nature

Menurut teori nature adanya pembedaan laki - laki dan perempuan adalah kodrat, sehingga 


\section{Ade Kartini, Asep Maulana}

harus diterima. Perbedaan biologis itu memberikan indikasi dan implikasi bahwa diantara kedua jenis kelamin tersebut memiliki peran dan tugas yang berbeda. Ada peran dan tugas yang dapat dipertukarkan, tetapi ada yang tidak bisa karena memang berbeda secara kodrat alamiahnya. Dalam proses perkembangannya, disadari bahwa ada beberapa kelemahan konsep nurture yang dirasa tidak menciptakan kedamaian dan keharmonisan dalam kehidupan berkeluarga maupun bermasyarakat, yaitu terjadi ketidak-adilan gender, maka beralih ke teori nature. Agregat ketidak-adilan gender dalam berbagai kehidupan lebih banyak dialami oleh perempuan, namun ketidak-adilan gender ini berdampak pula terhadap laki - laki.

3) Teori Equilibrium

Selain kedua aliran tersebut terdapat kompromistis yang dikenal dengan keseimbangan (equilibrium) yang menekankan pada konsep kemitraan dan keharmonisan dalam hubungan antara perempuan dengan laki-laki. Pandangan ini tidak mempertentangkan antara kaum perempuan dan laki-laki, karena keduanya harus bekerja sama dalam kemitraan dan keharmonisan dalam kehidupan keluarga, masyarakat, bangsa dan Negara. Untuk mewujudkan gagasan tersebut, maka dalam setiap kebijakan dan strategi pembangunan agar diperhitungkan kepentingan dan peran perempuan dan laki-laki secara seimbang. Hubungan diantara kedua elemen tersebut bukan saling bertentangan tetapi hubungan komplementer guna saling melengkapi satu sama lain. R.H. Tawney menyebutkan bahwa keragaman peran apakah karena faktor biologis, etnis, aspirasi, minat, pilihan, atau budaya pada hakikatnya adalah realita kehidupan manusia. Hubungan lakilaki dan perempuan bukan dilandasi konflik dikotomis, bukan pula 
Vol. 12, No. 2, Oktober 2019

p-ISSN:2086 -0749

e-ISSN:2654-4784

struktural fungsional, tetapi lebih dilandasi kebutuhan kebersamaan guna membangun kemitraan yang hamonis, karena setiap pihak memiliki kelebihan sekaligus kelemahan yang perlu diisi dan dilengkapi pihak lain dalam kerjasama yang setara. ${ }^{13}$

Dalam upaya mengubah perilaku seseorang terhadap pemahaman gender, ada beberapa istilah yang perlu diketahui:

1) Buta Gender (gender blind), yaitu kondisi/keadaan seseorang yang tidak memahami tentang pengertian/konsep gender karena ada perbedaan kepentingan laki-laki dan perempuan.

2) Sadar Gender (gender awareness), yaitu kondisi/keadaan seseorang yang sudah

13 Sri Sundari Sasongko, Konsep dan Teori Gender, ... hlm. 25 menyadari kesamaan hak dan kewajiban antara perempuan dan laki-laki.

3) Peka/Sensitif Gender (gender sensitive), yaitu kemampuan dan kepekaan seseorang dalam melihat dan menilai hasil pembangunan dan aspek kehidupan lainnya dari perspektif gender (disesuaikan kepentingan yang berbeda antara laki-laki dan perempuan).

4) Mawas Gender (gender perspective), yaitu kemampuan seseorang memandang suatu keadaan berdasarkan perspektif gender.

5) Peduli/Responsif Gender (gender concern/responcive), yaitu kebijakan/program/kegiatan atau kondisi yang sudah dilakukan dengan memperhi- 
tungkan kepentingan kedua jenis kelamin.

Untuk memahami gender lebih lanjut, perlu diperhatikan juga mengenai terjadinya ketidakadilan gender. Ketidakadilan gender atau diskriminasi gender merupakan akibat dari adanya sistem (struktur) sosial dimana salah satu jenis kelamin (laki-laki maupun perempuan) menjadi korban. Hal ini terjadi karena adanya keyakinan dan pembenaran yang ditanamkan sepanjang peradaban manusia dalam berbagai bentuk dan cara yang menimpa kedua belah pihak, walaupun dalam kehidupan sehari-hari lebih banyak dialami oleh perempuan. Ketidakadilan atau diskriminasi gender sering terjadi dalam keluarga dan masyarakat serta di tempat kerja dalam berbagai bentuk, yaitu:

1) Stereotip/Citra Baku, yaitu pelabelan terhadap salah satu jenis kelamin yang seringkali bersifat negatif dan pada umumnya me- nyebabkan terjadinya ketidakadilan. Misalnya, karena perempuan dianggap ramah, lembut, rapi, maka lebih pantas bekerja sebagai sekretaris, guru Taman $\mathrm{Ka}$ nak-kanak; kaum perempuan ramah dianggap genit; kaum laki-laki ramah dianggap perayu.

2) Subordina-

si/Penomorduaan, yaitu adanya anggapan bahwa salah satu jenis kelamin dianggap lebih rendah atau dinomorduakan posisinya dibandingkan dengan jenis kelamin lainnya. Contoh: Sejak dulu, perempuan mengurus pekerjaan domestik sehingga perempuan dianggap sebagai "orang rumah" atau "teman yang ada di belakang".

3) Marginalisasi/Peminggiran, adalah kondisi atau proses peminggiran terhadap salah satu jenis kelamin dari 
arus/pekerjaan utama yang berakibat kemiskinan.

Misalnya, perkembangan teknologi menyebabkan sesuatu yang semula dikerjakan secara manual oleh perempuan diambil alih oleh mesin yang pada umumnya dikerjakan oleh laki-laki.

4) Beban Ganda/Double Burden, adalah adanya perlakuan terhadap salah satu jenis kelamin dimana yang bersangkutan bekerja jauh lebih banyak dibandingkan dengan jenis kelamin lainnya.

5) Kekerasan/Violence, yaitu suatu serangan terhadap fisik maupun psikologis seseorang, sehingga kekerasan tersebut tidak hanya menyangkut fisik (perkosaan, pemukulan), tetapi juga nonfisik (pelecehan seksual, ancaman, paksaan, yang bisa terjadi di rumah tangga, tempat kerja, tempat-tempat umum ${ }^{14}$.

\section{Persepsi antara Konsep}

\section{Gender dan Jenis Ke-}

lamin

a. Perbedaan Gender dan Jenis Kelamin

Untuk memahami konsep gender, harus dibedakan antara kata gender dengan kata seks secara utuh. Pengertian gender itu berbeda dengan pengertian jenis kelamin (seks). Gender adalah perbedaan peran, fungsi, dan tanggungjawab antara laki-laki dan perempuan yang merupakan hasil konstruksi sosial dan dapat berubah sesuai dengan perkembangan jaman.

\footnotetext{
14 Sri Sundari Sasongko, Konsep dan Teori Gender, ..., hlm. 9-11
} 


\section{Ade Kartini, Asep Maulana}

Pengertian seks adalah perbedaan jenis kelamin yang ditentukan secara biologis. Seks melekat secara fisik pada masingmasing jenis kelamin, laki-laki dan perempuan sebagai alat reproduksi. Perbedaan jenis kelamin merupakan ketentuan Tuhan. Jenis kelamin biologis inilah bersifat kodrati, tidak dapat berubah, tidak dapat dilawan, tidak dapat dipertukarkan, dan berlaku sepanjang zaman sampai akhir hayat, sehingga bersifat permanen dan universal.

Penjelasan mengenai hal agar lebih rinci di atas dipaparkan dalam sebuah tabel. Di bawah ini merupakan tabel yang menjelaskan perbedaan gender dan seks.

\section{Tabel 2.1}

Perbedaan Gender dan Seks ${ }^{15}$

\begin{tabular}{|l|c|}
\hline \multicolumn{1}{|c|}{ Gender } & $\begin{array}{c}\text { Seks/Jenis } \\
\text { Kelamin }\end{array}$ \\
\hline 1. Bisa berubah & $\begin{array}{c}\text { 1. Tidak bisa } \\
\text { berubah }\end{array}$ \\
\hline
\end{tabular}

15 Sri Sundari Sasongko, Konsep dan Teori Gender, ..., hlm. 7

\begin{tabular}{|l|l|}
\hline tukarkan & 2. Tidak dapat \\
3. Tergantung & dipertukar- \\
musim & kan \\
4. Tergantung & 3. Berlaku \\
budaya masing- & sepanjang \\
masing & masa \\
5. Bukan ko- & 4. Berlaku di \\
drat & Tu- \\
han/buatan saja & 5. Kodrat (cip- \\
masyarakat & taan Tuhan) \\
\hline
\end{tabular}

Untuk lebih jelasnya di bawah ini disajikan contoh-contoh perbedaan konsep gender dan jenis kelamin dan perbedaan konsep kodrati dan bukan kodrati.

Tabel 2.2

Perbedaan konsep jenis kelamin (seks)/kodrati dan gender/ bukan kodrat beserta contohcontohnya ${ }^{16}$

\begin{tabular}{|c|c|}
\hline $\begin{array}{c}\text { Jenis Kelamin } \\
\text { (Seks) } \\
\text { Contoh kodrati }\end{array}$ & $\begin{array}{c}\text { Gender } \\
\text { Contoh Bukan } \\
\text { Kodrati }\end{array}$ \\
\hline $\begin{array}{l}\text { Peran reproduksi } \\
\text { kesehatan berlaku } \\
\text { sepanjang masa }\end{array}$ & $\begin{array}{l}\text { Peran sosial bergan- } \\
\text { tung pada waktu } \\
\text { dan keadaan }\end{array}$ \\
\hline Peran reproduksi & Peran sosial bukan \\
\hline
\end{tabular}

16 Herien Puspitawati, Gender dan Keluarga: ..., hlm. 28 


\begin{tabular}{|c|c|}
\hline $\begin{array}{l}\text { kesehatan diten- } \\
\text { tukan oleh Tuhan } \\
\text { atau kodrat }\end{array}$ & $\begin{array}{l}\text { kodrat Tuhan tapi } \\
\text { buatan manusia }\end{array}$ \\
\hline $\begin{array}{l}\text { Menyangkut } \\
\text { perbedaan organ } \\
\text { biologis laki-laki } \\
\text { dan perempuan } \\
\text { khususnya pada } \\
\text { bagian alat-alat } \\
\text { reproduksi. } \\
\text { Sebagai konsek- } \\
\text { uensi dari fungsi } \\
\text { alat-alat } \\
\text { reproduksi, maka } \\
\text { perempuan } \\
\text { mempunyai } \\
\text { fungsi reproduksi } \\
\text { seperti menstrua- } \\
\text { si, hamil, me- } \\
\text { lahirkan dan } \\
\text { menyusui; se- } \\
\text { dangkan laki-laki } \\
\text { mempunyai fungsi } \\
\text { membuahi (sper- } \\
\text { matozoid) }\end{array}$ & $\begin{array}{l}\text { Menyangkut perbe- } \\
\text { daan peran, fungsi, } \\
\text { dan } \\
\text { tanggung jawab } \\
\text { laki-laki dan per- } \\
\text { empuan sebagai } \\
\text { hasil kesepakatan } \\
\text { atau hasil bentukan } \\
\text { dari masyarakat. } \\
\text { Sebagai konsekuen- } \\
\text { si dari hasil kesepa- } \\
\text { katan masyarakat, } \\
\text { maka pembagian } \\
\text { peran laki-laki ada- } \\
\text { lah mencari nafkah } \\
\text { dan bekerja di } \\
\text { sektor publik, se- } \\
\text { dangkan peran per- } \\
\text { empuan di sektor } \\
\text { domestik dan ber- } \\
\text { tanggung jawab } \\
\text { masalah ru- } \\
\text { mahtangga }\end{array}$ \\
\hline $\begin{array}{l}\text { Peran reproduksi } \\
\text { tidak dapat beru- } \\
\text { bah; sekali men- } \\
\text { jadi perempuan }\end{array}$ & $\begin{array}{l}\text { Peran sosial dapat } \\
\text { berubah: } \\
\text { Peran istri sebagai } \\
\text { ibu rumahtangga }\end{array}$ \\
\hline
\end{tabular}

\begin{tabular}{|c|c|}
\hline $\begin{array}{l}\text { dan mempunyai } \\
\text { rahim, maka } \\
\text { selamanya akan } \\
\text { menjadi per- } \\
\text { empuan; se- } \\
\text { baliknya sekali } \\
\text { menjadi laki-laki, } \\
\text { mempunyai penis, } \\
\text { maka selamanya } \\
\text { menjadi laki-laki }\end{array}$ & $\begin{array}{l}\text { dapat berubah men- } \\
\text { jadi pekerja/pencari } \\
\text { nafkah, disamping } \\
\text { masih menjadi istri } \\
\text { juga }\end{array}$ \\
\hline $\begin{array}{l}\text { Peran reproduksi } \\
\text { tidak dapat diper- } \\
\text { tukarkan: tidak } \\
\text { mungkin peran } \\
\text { laki-laki me- } \\
\text { lahirkan dan per- } \\
\text { empuan mem- } \\
\text { buahi }\end{array}$ & 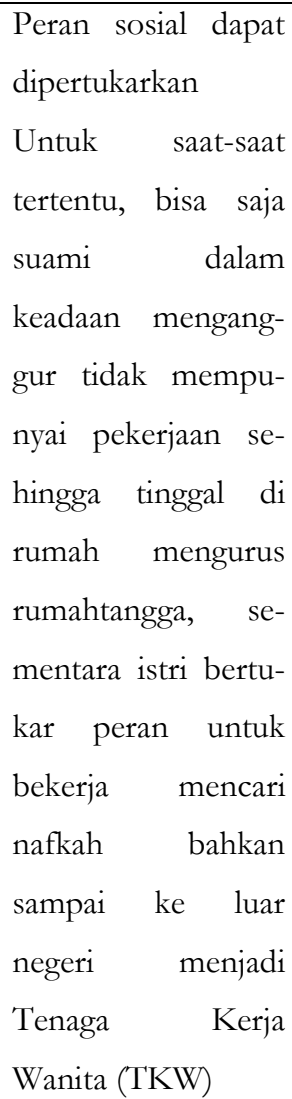 \\
\hline Membuahi & Bekerja di dalam \\
\hline
\end{tabular}




\begin{tabular}{|c|c|}
\hline & $\begin{array}{l}\text { rumah dan dibayar } \\
\text { (pekerjaan pub- } \\
\text { lik/produktif di } \\
\text { dalam rumah) sep- } \\
\text { erti jualan masakan, } \\
\text { pelayanan } \\
\text { kesehatan, membu- } \\
\text { ka salon kecantikan, } \\
\text { menjahit/ tailor, } \\
\text { mencuci paka- } \\
\text { ian/loundry, } \\
\text { mengasuh dan } \\
\text { mendidik anak } \\
\text { orang lain (babby- } \\
\text { sitter/ pre-school) }\end{array}$ \\
\hline Menstruasi & $\begin{array}{l}\text { Bekerja di luar ru- } \\
\text { mah dan dibayar } \\
\text { (pekerjaan publik di } \\
\text { luar rumah) }\end{array}$ \\
\hline $\begin{array}{l}\text { Mengandung/ } \\
\text { hamil }\end{array}$ & $\begin{array}{l}\text { Bekerja di dalam } \\
\text { rumah dan tidak } \\
\text { dibayar } \\
\text { (pekerjaan domestik } \\
\text { rumahtangga) sep- } \\
\text { erti } \\
\text { memasak, menyapu } \\
\text { halaman, mem- } \\
\text { bersihkan rumah, } \\
\text { mencuci pakaian } \\
\text { keluarga, menjahit } \\
\text { pakaian keluarga }\end{array}$ \\
\hline $\begin{array}{l}\text { Melahirkan anak } \\
\text { bagi perempuan }\end{array}$ & $\begin{array}{l}\text { Bekerja di luar ru- } \\
\text { mah dan tidak }\end{array}$ \\
\hline
\end{tabular}

\begin{tabular}{|c|c|}
\hline & $\begin{array}{l}\text { dibayar (kegiatan } \\
\text { sosial kemasyara- } \\
\text { katan) bagi laki-laki } \\
\text { dan perempuan }\end{array}$ \\
\hline $\begin{array}{l}\text { Menyusui anak/ } \\
\text { bayi dengan } \\
\text { payudaranya bagi } \\
\text { Perempuan }\end{array}$ & $\begin{array}{l}\text { Mengasuh anak } \\
\text { kandung, me- } \\
\text { mandikan, men- } \\
\text { didik, membacakan } \\
\text { buku cerita, mene- } \\
\text { mani tidur. Me- } \\
\text { nyusui anak bayi } \\
\text { dengan } \\
\text { menggunakan botol } \\
\text { bagi laki-lakiatau } \\
\text { perempuan }\end{array}$ \\
\hline $\begin{array}{l}\text { Sakit prostat un- } \\
\text { tuk laki-laki }\end{array}$ & $\begin{array}{l}\text { Mengangkat beban, } \\
\text { memindahkan ba- } \\
\text { rang, } \\
\text { membetulkan } \\
\text { perabot dapur, } \\
\text { memperbaiki listrik } \\
\text { dan lampu, me- } \\
\text { manjat pohon/ } \\
\text { pagar bagi laki-laki } \\
\text { atau perempuan }\end{array}$ \\
\hline $\begin{array}{l}\text { Sakit kanker } \\
\text { rahim untuk per- } \\
\text { empuan }\end{array}$ & $\begin{array}{l}\text { Menempuh pen- } \\
\text { didikan tinggi, men- } \\
\text { jadi pejabat publik, } \\
\text { menjadi dokter, } \\
\text { menjadi tentara } \\
\text { militer, menjadi } \\
\text { koki, menjadi guru } \\
\text { TK/SD, memilih }\end{array}$ \\
\hline
\end{tabular}


Vol. 12, No. 2, Oktober 2019

p-ISSN:2086 -0749

e-ISSN:2654-4784

\begin{tabular}{|l|l|}
\hline PMK-Tehnik In- & studi \\
Sustri, memilih \\
program studi me- \\
masak dan merias \\
bagi laki-laki atau \\
perempuan.
\end{tabular}

Konsep gender menjadi persoalan yang menimbulkan pro dan kontra baik di kalangan masyarakat, akademisi, maupun pemerintahan sejak dahulu dan bahkan sampai sekarang. Pada umumnya sebagian masyarakat merasa terancam dan terusik pada saat mendengar kata "gender". Berdasarkan diskusi dengan berbagai kalangan, keengganan masyarakat untuk menerima konsep gender disebabkan oleh halhal sebagai berikut ${ }^{17}$ :

1) Konsep gender berasal dari negara-negara Barat, sehingga sebagian masyarakat

\footnotetext{
17 Herien Puspitawati, Gender dan Keluarga: ..., hlm. 37
}

2) Menganggap bahwa gender merupakan propaganda nilai-nilai Barat yang sengaja disebarkan untuk merubah tatanan masyarakat khususnya di Timur.

3) Konsep gender merupakan gerakan yang membahayakan karena dapat memutarbalikkan ajaran agama dan budaya, karena konsep gender berlawanan dengan kodrati manusia.

4) Konsep gender berasal dari adanya kemarahan dan kefrustrasian kaum perempuan untuk menuntut haknya sehingga menyamai kedudukan laki-laki. Hal ini dikarenakan kaum perempuan merasa dirampas haknya oleh kaum laki-laki. Di Indonesia tidak ada masalah gender karena negara sudah menjamin seluruh 
Ade Kartini, Asep Maulana

warga negara untuk mempunyai hak yang sama sesuai dengan yang tercantum pada UUD 1945.

5) Adanya mind set yang sangat kaku dan konservatif di sebagian masyarakat, yaitu mind set tentang pembagian peran antara laki-laki dan perempuan adalah sudah ditakdirkan dan tidak perlu untuk dirubah (misalnya kodrati perempuan adalah mengasuh anak, kodrati laki-laki mencari nafkah). Namun mind-set ini sepertinya masih terus berlaku meskipun mengabaikan fakta bahwa semakin banyak perempuan Indonesia menjadi Tenaga Kerja Wanita (TKW) ke luar negeri dan mengambil alih tugas suami sebagai pencari nafkah utama.

Untuk mencapai pembangunan yang berkeadilan dan berkesetaraan gender (gender equali- ty) dan keadilan gender (gender equity), maka harus ada relasi gender yang harmonis antara laki-laki dan perempuan. Berikut ini dipaparkan mengenai kesetaraan dan keadilan gender.

b. Konsep Kesetaraan dan Keadilan Gender

Kesetaraan gender merupakan kondisi perempuan dan lakilaki menikmati status yang setara dan memiliki kondisi yang sama untuk mewujudkan secara penuh hak-hak asasi dan potensinya bagi pembangunan di segala bidang kehidupan. Definisi dari USAID menyebutkan bahwa "Gender Equality permits women and men equal enjoyment of human rights, socially valued goods, opportunities, resources and the benefits from development results". (kesetaraan gender memberi kesempatan baik pada perempuan maupun laki-laki untuk secara setara/sama/sebanding menikmati hak-haknya sebagai manusia, secara sosial mempunyai bendabenda, kesempatan, sumberdaya 
dan menikmati manfaat dari hasil pembangunan).

Keadilan gender adalah suatu kondisi adil untuk perempuan dan laki-laki melalui proses budaya dan kebijakan yang menghilangkan hambatanhambatan berperan bagi perempuan dan laki-laki. Definisi dari USAID menyebutkan bahwa "Gender Equity is the process of being fair to women and men. To ensure fairness, measures must be available to compensate for historical and social disadvantages that prevent women and men from operating on a level playing field. Gender equity strategies are used to eventually gain gender equality. Equity is the means; equality is the result". (Keadilan gender merupakan suatu proses untuk menjadi fair baik pada perempuan maupun laki-laki. Untuk memastikan adanya fair, harus tersedia suatu ukuran untuk mengompensasi kerugian secara histori maupun sosial yang mencegah perempuan dan lakilaki dari berlakunya suatu tahapan permainan. Strategi keadilan gender pada akhirnya digunakan untuk meningkatkan kesetaraan gender. Keadilan merupakan cara, kesetaraan adalah hasilnya). ${ }^{18}$

Kesetaaraan gender (gender equality) berarti posisi yang sama antara laki-laki dan perempuan dalam memperoleh akses, partisipasi, kontrol, dan manfaat dalam aktivitas kehidupan baik dalam keluarga, masyarakat maupun berbangsa dan bernegara. Keadilan gender (gender equity) adalah suatu proses menuju selaras, seimbang, serasi, tanpa diskriminasi. Pelaksanaan Pengarusutamaan Gender di Daerah, disebutkan kesetaraan dan keadilan gender adalah suatu kondisi yang adil

18 Herien Puspitawati, Gender dan Keluarga: ..., hlm. 43 


\section{Ade Kartini, Asep Maulana}

dan setara dalam hubungan kerjasama antara perempuan dan lakilaki. ${ }^{19}$

\section{Simpulan}

Gender merupakan pembahasan yang tidak akan ada habisnya untuk dibahas. Ia akan senantiasa melekat seiring dengan perkembangan jaman yang mampu menggeser perubahan cara berpikir dan tatanan sosial. Gender adalah suatu konsep yang mengkaji tentang perbedaan antara laki-laki dan perempuan sebagai hasil dari pembentukan kepribadian yang berasal dari masyarakat (kondisi sosial, adatistiadat dan kebudayaan yang berlaku). Gender merupakan perbedaan peran, fungsi, dan tanggung jawab antara laki-laki dan perempuan yang merupakan hasil konstruksi sosial dan dapat berubah sesuai dengan perkembangan jaman. Hal tersebut harus

${ }^{19}$ Mufidah, Ch., Psikologi Keluarga Islam Berwawasan Gender, (Malang: UIN-Maliki Press, 2013), hlm. 15 dibedakan dengan posisi laki-laki dan perempuan dari segi jenis kelamin yang telah digariskan secara kodrati.

Pembahasan gender dalam makalah ini belum sempurna. Masih banyak permasalahan gender yang belum dikupas tuntas. Harapan besar pembaca bisa melengkapi pengetahuan dan wawasan gender ini dengan lebih luas. Beberapa tema penting masih bisa dibahas seperti konsep gender menurut Islam dalam perspektif Alquran dan hadis.

\section{Daftar Pustaka}

Al-Maraghi, Ahmad Musthafa. 1989. Terjemah Tafsir AlMaraghi, jilid 36, cet.1. Semarang: Toha Putra

Baidhowi, Ahmad. 2005. Tafsir Feminis, Kajian Perempuan dalam Al-Qur'an dan $\quad P a-$ ra Mufasir Kontemporer. Bandung: Nuansa

Ch., Mufidah. 2013. Psikologi Keluarga Islam Berwawasan Gender. Malang: UINMaliki Press. 
An-Nisa' : Jurnal Kajian Perempuan \& Keislaman

Vol. 12, No. 2, Oktober 2019

p-ISSN:2086 -0749

e-ISSN:2654-4784

Fakih, Mansour. 1997. Analisis Gender dan Transformasi Sosial. Yogyakarta: Pustaka Pelajar

Istibsyaroh. 2004. Hak-Hak Perempuan, Relasi Jender Menurut Tafsir Al-Sya'rawi. Jakarta: Teraju

Makalah Pelatihan. 2005 "Cefil, Civic Education and Future Indonesia Leaders". Di Satunama Yogyakarta: 130 Agustus 2012

Puspitawati, Herien. 2012. Gender dan Keluarga: Konsep dan Realita di Indonesia, Bogor: PT IPB Press

Sasongko, Sri Sundari. 2009. Konsep dan Teori Gender, Program Pembinaan Jarak Jauh Pengarusutamaan Gender Modul 2, cet.2, Pusat Pelatihan Gender dan Peningkatan Kualitas Perempuan BKKBN. Jakarta: $\mathrm{BKKBN}$

Sodik, M dan Inayah. 2003. Perempuan Tertindas, Kajian Hadits-hadits "Misoginis". Yogyakarta: PSW IAIN Sunan Kalijaga
Umar, Nasaruddin. 2001. Argumen Kesetaraan Jender Perspektif AlQur'an. Jakarta: Paramadina

http://ikk.fema.ipb.ac.id/v2/imag es/karyailmiah/gender.pdf http://www.bappenas.go.id /files/4513/5027/3745/19july-2012-prest-yulfita--bagi-eselon-1-dan-2-

fi-

nal_20120720144628_0.p df 